\title{
HUBUNGAN PENDIDIKAN, MOTIVASI KERJA, SUPERVISI KEPALA RUANGAN DENGAN KINERJA PERAWAT RSUD H.HANAFIE MUARA BUNGO
}

\author{
${ }^{1}$ Maulani ${ }^{2}$ Dasuki \\ 1,2, Program Studi Profesi Ners STIKES Harapan Ibu, Jambi, Indonesia.
}

\begin{abstract}
ABSTRAK
Kinerja perawat yang baik diharapkan dapat meningkatkan Asuhan keperawatan yang bermuara pada kualitas hidup dan kesejahteraan pasien. Kinerja perawat dipengaruhi oleh tingkat pendidikan, motivasi kerja dan supervisi kepala ruangan. Penelitian ini merupakan penelitian quantitatif, dengan desain cross sectional yang bertujuan untuk melihat gambaran dan hubungan tingkat pendidikan, motivasi kerja dan supervisi kepala ruangan dengan kinerja perawat RSUD H.Hanafie Muara Bungo Tahun 2015 dengan jumlah sampel sebanyak 63 orang, dimana pengambilan sampel dilakukan dengan tehnik Simple Random Sampling. Pengumpulan data dilakukan dengan menggunakan lembar kuesioner,dan data dianalisis univariat dan bivariat dengan uji chi square. Hasil penelitian diketahui bahwa rata-rata responden memiliki tingkat pendidikan perawat pemula sebanyak $92,1 \%$, yang memiliki motivasi kerja tinggi sebanyak 50,8\%, dan supervisi kepala ruangan yang baik 52,4\%, rata-rata kinerja perawat yang baik sebanyak 52,4\%. Tidak ada hubungan antara tingkat pendidikan dengan kinerja perawat dengan nilai $P$ value 0,912, ada hubungan yang signifikan antara supervisi kepala ruangan dengan nilai $P$-value 0,000dan motivasi kerja dengan nilai $P$-value 0,000 dengan kinerja perawat. Penelitian ini menunjukkan bahwa tidak ada hubungan antara tingkat pendidikan dengan kinerja perawat, namun ada hubungan antara supervisi,dan motivasi kerja dengan kinerja perawat.
\end{abstract}

Kata kunci $\quad$ : Kinerja perawat, motivasi, pendidikan, supervisi

\begin{abstract}
Background: Good performance of nurse is expected to improve nursing care which affected to the quality of life and well-being of the patient. The performance of nurses is influenced by the level of education, working motivation and supervision of the head of the room.

Methods: This study is a quantitative with cross sectional approach. The population of this study was all the 146 nurses who were in the Inpatient room at H.Hanafie General Hospital in MuaraBungo. It used Simple Random Sampling technique, in fact the total of samples were 63 respondents. This research was conducted from 23 December 2015 to 6 January 2016. The data was collected by using questionnaire and then data were analyzed by using univariate and bivariate analysis with chi square test.

Results: The results reveal that the average respondent have a beginner level of nursing education (92.1\%), those who have high motivation to work as much as 50.8\%, and the supervision of the head of the room was good $(52.4 \%)$, the average of good nurse performance as much as 52.4\%. The education level of nurses with $P$-value of 0.912 , the supervision of the head of the room with a P-value of 0.000 and motivation to work with P-value of 0.000 .

Conclusion: It can be concluded that there is no correlation between level of education and the performance of nurses. Also, there is a correlaton between supervision and performance of nurses, on the other hand there is a correlation between motivation to work and performance of nurses.
\end{abstract}

Keywords: performance of nurses, motivation, education, supervision

1. Stikes Harapan Ibu Jambi, 085266198486,E-mail:mhee114n3@gmail.com

2. Stikes Harapan Ibu Jambi, 081298852873, E-mail:dasukisuke@gmail.com 


\section{PENDAHULUAN}

Profesi keperawatan merupakan suatu bagian utama dalam sistem kesehatan dan menjadi kunci utama disamping dokter dalam memberikan pelayanan kesehatan di Rumah Sakit. Peran dan tanggung jawab kedua profesi tersebut secara langsung berdampak pada hasil akhir pelayanan klien selama di Rumah Sakit. Seperti bertambahnya jumlah dan hari perawatan. ${ }^{1}$

Perawat merupakan sumber daya manusia yang terpenting di Rumah Sakit karena selain jumlahnya yang dominan (55$65 \%$ ) juga memberikan pelayanan yang konstan dan terus menerus 24 jam kepada pasien setiap hari. Oleh karena itu, pelayanan keperawatan sebagai bagian integral dari pelayanan kesehatan jelas menentukan kualitas pelayanan di Rumah Sakit, sehingga setiap upaya untuk meningkatkan kualitas pelayanan Rumah Sakit harus juga disertai upaya untuk meningkatkan kualitas pelayanan keperawatan. $^{2}$

Pelayanan keperawatan dapat dinilai melalui kinerja perawat. Kinerja perawat dapat dilihat dari cara kerja yang penuh semangat, disiplin, bertanggung jawab, melaksanakan tugas sesuai standar yang ditetapkan, memiliki motivasi dan kemampuan kerja yang tinggi dan terarah pada pencapaian tujuan rumah sakit. Penilaian kinerja perawat salah satunya adalah dengan melakukan penilaian terhadap kegiatan perawat dalam memberikan asuhan keperawatan sesuai dengan SOP (Standar Operasional Prosedur) dan SAK (Standar Asuhan Keperawatan). ${ }^{1}$ Masalah utama kinerja perawat dalam pelayanan keperawatan adalah kurangnya perawat yang berpendidikan tinggi, kemampuan yang tidak memadai, juga beban kinerja yang tinggi. ${ }^{3}$

Agar tercapainya tujuan asuhan keperawatan secara efektif dan efisien, maka perlu dilakukan supervisi khususnya di bidang keperawatan mencakup pemantauan kondisi-kondisi atau syarat-syarat personal maupun material yang diperlukan untuk mempertahankan kegiatan yang telah terprogram dapat dilaksanakan dengan baik dan lancar. ${ }^{4}$

Kinerja yang baik harus dilandasi motivasi yang kuat, tanpa motivasi maka tidak ada dorongan untuk menghasilkan kinerja yang baik. Adanya motivasi kinerja yang tinggi dalam lingkungan kerja akan menghasilkan rasa bangga, puas dalam melakukan tugas, dan pekerjaannya secara tuntas, selain motivasi, tingkat pendidikan juga sangat berpengaruh terhadap kinerja perawat dalam melakukan tindakan keperawatan yang professional. ${ }^{5}$ Penelitian ini bertujuan untuk melihat gambaran dan hubungan tingkat pendidikan, motivasi kerja dan supervisi kepala ruangan dengan kinerja perawat RSUD $\mathrm{H}$. Hanafie Muara Bungo Tahun 2015

\section{METODE}

Penelitian ini merupakan penelitian kuantitatif, menggunakan desain cross sectional. Populasi dalam penelitian ini adalah seluruh perawat yang bekerja di RSUD H.Hanafie Muara Bungo tahun 2015 berjumlah 146 orang. Sampel dalam penelitian ini adalah perawat yang berada di ruangan Rawat Inap berjumlah 63 orang. Tehnik pengambilan sampel menggunakan simple random sampling.

Pengambilan data dilakukan dengan menggunakan lembar kuesioner dan dianalisis secara univariat dan bivariat dengan uji chi square. Penelitian ini dilakukan pada bulan Desember 2015s/d Januari 2016.

\section{HASIL}

Hasil analisis univariat masing-masing variabel penelitian dapat dilihat pada tabel berikut ini :

Tabel 1. Distribusi frekuensi kinerja, tingkat pendidikan, motivasi kerja dan supervisi kepala ruangan di RS. H.Hanafie tahun 2015 ( $\mathrm{N}=63$ Orang)

\begin{tabular}{lcc}
\hline \multicolumn{1}{c}{ variabel } & Frekuensi (n) & Persentase (\%) \\
\hline Kinerja perawat & 30 & 47,6 \\
Kurang baik & 33 & 52,4 \\
Baik & & \\
& & \\
Tingkat pendidikan & 58 & 92,1 \\
Perawat pemula & 5 & 7,9 \\
Perawat professional & & \\
Motivasi kerja & 31 & 49,2 \\
Rendah & 32 & 50,8 \\
Tinggi & & \\
Supervisi & & \\
ruangan & & \\
Kurang baik & 30 & \\
\hline
\end{tabular}


Berdasarkan Tabel 1, sebagian besar responden mempunyai kinerja yang baik $(52,4 \%)$, dengan tingkat pendidikan perawat pemula $(92,1 \%)$, serta memiliki motivasi kerja tinggi (50,8\%), dengan responden yang menilai supervisi bidang keperawatan baik sebanyak 33 responden $(52,4 \%)$.

Tabel 2. Analisis bivariat hubungan tingkat pendidikan motivasi kerja dan supervisi kepala ruangan dengan kinerja perawat di Rumah Sakit Umum Daerah H.Hanafie Muara Bungo tahun 2015

\begin{tabular}{|c|c|c|c|c|c|c|c|}
\hline \multirow{3}{*}{ Variabel } & \multicolumn{4}{|c|}{ Kinerja Perawat } & \multirow{2}{*}{\multicolumn{2}{|c|}{ Total }} & \multirow{3}{*}{$p$} \\
\hline & \multicolumn{2}{|c|}{ Kurang Baik } & \multicolumn{2}{|c|}{ Baik } & & & \\
\hline & Jmlh & $\%$ & Jmlh & $\%$ & Jmlh & $\%$ & \\
\hline
\end{tabular}

\begin{tabular}{|c|c|c|c|c|c|c|c|}
\hline \multicolumn{8}{|l|}{$\begin{array}{l}\text { Tingkat } \\
\text { pendidikan }\end{array}$} \\
\hline Pemula & 27 & 46,6 & 31 & 53,4 & 58 & 100,0 & 0,912 \\
\hline Professional & 3 & 60,0 & 2 & 40,0 & 5 & 100,0 & \\
\hline \multicolumn{8}{|l|}{ Motivasi } \\
\hline \multicolumn{8}{|l|}{ kerja } \\
\hline Rendah & 23 & 74,2 & 8 & 25,8 & 31 & 100,0 & 00,000 \\
\hline tinggi & 7 & 21,9 & 25 & 78,1 & 32 & 100,0 & \\
\hline \multicolumn{8}{|l|}{ Supervisi } \\
\hline \multicolumn{8}{|l|}{ kepala } \\
\hline \multicolumn{8}{|l|}{ ruangan } \\
\hline Kurang baik & 23 & 76,7 & 7 & 23,3 & 30 & 100,0 & 0,000 \\
\hline baik & 7 & 21,2 & 26 & 78,8 & 33 & 100,0 & \\
\hline
\end{tabular}

Berdasarkan Tabel 2, pada hasil analisis bivariat diketahui tidak ada hubungan yang signifikan antara tingkat pendidikan perawat dengan kinerja perawat $(p$-value $=0,912)$, namun ada hubungan yang signifikan antara motivasi kerja $(p$-value $=0,000)$, supervisi kepala ruangan $(p$-value $=0,000)$ dengan kinerja perawat

\section{PEMBAHASAN}

\section{Hubungan Tingkat Pendidikan Dengan Kinerja Perawat.}

Berdasarkan hasil analisis uji secara statistic diperoleh $p$-value $=0,912$ lebih besar dari taraf signifikansi 0,05. Dapat disimpulkan dari hasil tersebut bahwa tidak terdapat hubungan yang signifikan antara tingkat pendidikan perawat dengan kinerja perawat.
Hasil Penelitian ini sejalan dengan penelitian sebelumnya dengan nilai $p$-value 0,902 , yang berarti tidak ada hubungan antara tingkat pendidikan dengan kinerja perawat. ${ }^{6}$ Hasil penelitian yang dilakukan di RS. Muhammadiyah Palembang juga diketahui tidak ada pengaruh pendidikan terhadap kinerja Perawat dengan $p$ - value 1,000 (> $0,25)^{7}$

Pendidikan merupakan salah satu karakteristik demografi yang dapat mempengaruhi seseorang baik terhadap lingkungan maupun obyek tertentu. Selain itu, pendidikan merupakan faktor tidak langsung yang berpengaruh pada kinerja. Semakin tinggi pendidikan seseorang maka besar keinginan untuk memanfaatkan pengetahuan dan keterampilan yang dimilikinya sehingga dapat menghasilkan kinerja yang tinggi. ${ }^{8}$ Namun pada penelitian ini diketahui dari 58 responden dengan tingkat pendidikan pemula diketahui $31 \quad(53,4 \%)$ mempunyai kinerja yang baik, sedangkan dari 5 responden dengan tingkat pendidikan profesional sebanyak $3(60,0 \%)$ mempunyai kinerja yang kurang baik.

Pendidikan merupakan faktor yang mempengaruhi kinerja seseorang namun dalam penelitian ini banyak faktor lain juga mempengaruhi kinerja seseorang, diantaranya disebabkan karena jumlah sampel yang tidak merata, selain itu meskipun sebagian besar responden mempunyai tingkat pendidikan pemula, namun mempunyai pengalaman kerja yang sudah lama, dan sering mendapatkan pelatihan. Dengan mengikuti pelatihan dapat meningkatkan pengetahuan dan keterampilan klinik yang juga menentukan kinerja seseorang. Menurut peneliti faktor ini lah yang menyebabkan tidak adanya hubungan pendidikan dengan kinerja perawat.

\section{Hubungan Motivasi Kerja Dengan Kinerja Perawat.}

Hasil penelitian diketahui ada hubungan bermakna antara motivasi kerja dengan kinerja perawat dengan nilai $p$-value $=0,000(p=0,05)$.

Motivasi diartikan sebagai kekuatan, dorongan, kebutuhan, semangat, tekanan atau mekanisme psikologis yang mendorong seseorang atau kelompok untuk mencapai prestasi tertentu sesuai dengan apa yang dikehendakinya. Kekuatan, dorongan, kebutuhan, tekanan, dan mekanisme 
psikologis yang dimaksudkan di atas merupakan akumulasi faktor-faktor internal dan eksternal. Faktor internal bersumber dari dalam diri individu itu sendiri, sedangkan faktor eksternal bersumber dari luar individu. ${ }^{9}$

Motivasi adalah karakteristik psikologis manusia yang memberi konstribusi pada tingkat komitmen seseorang. Hal ini temasuk faktor-faktor yang menyebabkan, menyalurkan dan mempertahankan tingkah laku manusia dalam arah tertentu. ${ }^{\mathbf{1 0}}$

Hasil penelitian dari 31 responden dengan motivasi rendah, diketahui 23 (74,2\%) mempunyai kinerja kurang baik, berdasarkan keterangan dari responden rendahnya motivasi kerja disebabkan gaji yang diterima tidak sesuai dengan jerih payah yang dikeluarkan, Kurangnya penghargaan dari atasan, pekerjaan terasa membosankan dan kurangnya fasilitas rekreasi yang tersedia. Sesuai dengan hasil penelitian yang dilakukan sebelumnya yang menunjukkan terdapat hubungan antara imbalan dengan kinerja perawat dalam melaksanakan asuhan keperawatan di ruang rawat inap, dimana rendahnya imbalan yang diterima menjadikan rendahnya kinerja perawat dalam melaksanakan asuhan keperawatan. ${ }^{11}$

Hal ini sejalan dengan teori Maslow, bahwa tindakan atau tingkah laku manusia pada suatu saat ditentukan oleh kebutuhan yang paling mendesak. Jika pada suatu saat kebutuhan primer terpenuhi, maka orang akan memenuhi kebutuhan pada tingkat yang lebih tinggi. Kebutuhan tersebut meliputi fisiologis dengan pemberian gaji yang lebih layak, rasa aman dan nyaman dengan memfasilitasi kebutuhan rekreasi, kebutuhan social dengan menghargai dan mengakui keberadaan perawat pelaksana serta kebutuhan lainnya dengan mengakui staff sebagai anggota kelompok kerja dalam melakukan interksi kerja yang baik dah hubungan kerja yang harmonis. ${ }^{12}$ Faktor finansial (gaji) merupakan faktor yang dapat meningkatkan kerja staf. ${ }^{\mathbf{1 0}}$

Dari 32 responden dengan motivasi kerja tinggi diperoleh $25(78,1 \%)$ mempunyai kinerja yang baik. Hal ini disebabkan karena perawat selalu bekerja sebaik mungkin sesuai dengan tanggungjawab, pekerjaan merupakan pekerjaan yang banyak diinginkan oleh orang lain, adanya penghargaan yang diberikan oleh atasan, dan tim kerja yang menyenangkan. Ini sejalan dengan penelitian terdahulu dimana tanggung jawab berhubungan dengan kinerja perawat di Ruang Rawat Inap Interna RSUD Daya Makassar. ${ }^{13}$ Dengan adanya tanggung jawab yang diberikan kepada perawat maka akan memotivasi untuk meningkatkan kinerjanya sesuai harapan dan tanggung jawab yang diberikan. Demikian juga dengan hasil penelitian di Rumah Sakit Bhayangkara Medan menunjukkan bahwa ada hubungan motivasi dengan kinerja perawat pelaksana. ${ }^{14}$

Motivasi tenaga kerja akan ditentukan oleh perangsangnya. Perangsang yang dimaksud merupakan mesin penggerak motivasi tenaga kerja, sehingga menimbulkan pengaruh perilaku individu tenaga kerja yang bersangkutan. Unsur-unsur penggerak motivasi antara lain kinerja, penghargaan, tantangan, tanggung jawab, pengembangan, keterlibatan, dan kesempatan. Seseorang yang memiliki keinginan untuk menjadikan kinerja sebagai suatu kebutuhan dapat mendorongnya untuk mencapai sasaran, adanya rasa takut dan memiliki akan menimbulkan motivasi untuk turut merasa bertanggung jawab, serta pengakuan atas suatu kinerja, akan memberikan kepuasan batin yang lebih tinggi daripada penghargaan dalam bentuk materi atau hadiah. Penghargaan atau pengakuan dalam bentuk piagam atau medali, dapat menjadikan perangsang yang lebih kuat dibandingkan dengan hadiah berupa barang, bonus atau uang. ${ }^{15}$

Hal ini sejalan dengan hasil penelitian sebelumnya dimana kinerja perawat yang baik sangat terkait dengan motivasi kerja dari perawat itu sendiri. Menurutnya, motivasi kerja dianggap suatu hal yang menentukan untuk menghasilkan sesuatu yang dapat memunculkan motivasi prestasi kerja yang tinggi. ${ }^{16}$ Hasil penelitian di RSUD Serui Papua didapatkan ada hubungan yang negatif antara motivasi kerja perawat dengan kecenderungan mengalami burnout pada perawat. Salah satu hal yang ditengarai dapat mempengaruhi terjadinya kecenderungan burnout yang dialami perawat adalah motivasi kerja. ${ }^{17}$ Setiap manusia mempunyai alasan tertentu bersedia melakukan jenis kegiatan atau pekerjaan tertentu, mengapa individu yang satu bekerja lebih giat, sedangkan yang lainnya bekerja dengan biasa saja, hal ini sangat tergantung pada motivasi yang mendasari individu tersebut. Motivasi sangat penting untuk dipahami karena melalui motivasi seseorang terdorong untuk melakukan suatu pekerjaan. ${ }^{18}$ 


\section{Hubungan Supervisi Kepala Ruangan Dengan Kinerja Perawat .}

Berdasarkan hasil penelitian diketahui hasil analisis hubungan supervisi kepala ruangan dengan kinerja perawat diperoleh data 30 responden yang menilai supervisi bidang keperawatan kurang baik diketahui sebanyak $23(76,7 \%)$ responden mempunyai kinerja yang kurang baik hal ini disebabkan karena perawat selalu mengeluh tentang kondisi lingkungan kerja, hasil pendapatan dan beban kerja yang tidak seimbang, perawat tidak bersedia dan terbuka menerima kritik dan saran perawat lain, hal ini didukung oleh penelitian

Tujuan supervisi adalah memberikan bantuan kepada bawahan secara langsung sehingga dengan bantuan tersebut bawahan akan memiliki bekal yang cukup untuk dapat melaksanakan tugas atau pekerjaan dengan hasil yang baik. Kegiatan supervisi mengusahakan seoptimal mungkin kondisi kerja yang kondusif dan nyaman yang mencakup lingkungan fisik, atmosfer kerja, dan jumlah sumber-sumber yang dibutuhkan untuk memudahkan pelaksanaan tugas. ${ }^{19}$

Sedangkan dari 33 responden yang menilai supervisi bidang keperawatan baik diketahui sebanyak $26(78,8 \%)$ responden mempunyai kinerja yang baik, hal ini karena kepala ruangan selalu membantu perawat lain menyelesaikan tugas kerjanya, kepala ruangan melatih perawat untuk melaksanakan asuhan keperawatan dengan baik dan benar, mencatat asuhan keperawatan sesuai dengan tindakan yang telah dilakukan dan cekatan atau terampil dalam memberikan pertolongan atau tindakan keperawatan. Hasil uji secara statistic diperoleh $p$-value $=0,000(\mathrm{p}<0,05)$ dapat disimpulkan bahwa ada hubungan yang signifikan antara supervisi dengan kinerja perawat.

Penelitian ini juga sejalan dengan penelitian sebelumnya, dimana supervisi RS berpengaruh positif terhadap kinerja di RS Stella Maris. ${ }^{20}$ Hasil penelitian pada tahun 2015 juga diketahui terdapat hubungan yang bermakna antara supervisi dengan kinerja perawat. ${ }^{21}$ Hal ini sejalan dengan hasil penelitian lainnya bahwa peran supervisi kepala ruangan sebagai pengamat atau pengawas serta penilai, berhubungan dengan kinerja perawat pelaksana dalam pelaksanaan asuhan keperawatan. ${ }^{22}$
Apabila supervisi dapat dilakukan dengan baik akan diperoleh banyak manfaat, diantaranya lebih meningkatkan efektivitas kerja. Peningkatan efektivitas kerja ini erat hubungannya dengan peningkatan pengetahuan dan keterampilan bawahan serta makin terbinanya hubungan dan suasana kerja yang lebih harmonis antara atasan dan bawahan.9

Supervisi merupakan pengamatan langsung dan berkala oleh atasan terhadap pekerjaan yang dilakukan bawahan untuk kemudian bila ditemukan masalah segera diberikan bantuan yang bersifat langsung guna mengatasinya. Supervisi adalah merencanakan, mengarahkan, membimbing, mengajar, mengobservasi, mendorong, memperbaiki, mempercayai, mengevaluasi secara terus menerus pada setiap perawat dengan sabar adil dan bijaksana. Dengan demikian diharapkan setiap perawat dapat memberikan asuhan keperawatan dengan baik, terampil, aman, cepat dan tepat secara menyeluruh $^{23}$

Untuk itu diharapkan adanya kesadaran internal bidang keperawatan, agar dapat memacu diri untuk meningkatkan peran supervisi yang lebih baik terutama supervisi kepala ruangan dalam pemberian asuhan keperawatan sesuai dengan standar yang telah ditetapkan dan harus diterapkan oleh seorang perawat, baik dalam memberikan pembinaan, bantuan, keterampilan maupun penguatan dalam melaksanakan seluruh rangkaian proses asuhan keperawatan yang lebih baik, yang akhirnya dapat meningkatkan prestasi kerja dan kinerja perawat.

\section{KESIMPULAN}

Berdasarkan hasil penelitian didapatkan kesimpulan sebagai berikut :

1. Dari 63 orang responden, 58 responden $(92,1 \%)$ mempunyai tingkat pendidikan pemula, 32 responden $(50,8 \%)$ mempunyai motivasi kerja yang tinggi, dan 33 responden $(52,4 \%)$ menilai kepala ruangan melakukan supervisi dengan baik, serta 33 responden $(52,4 \%)$ responden mempunyai kinerja yang baik.

2. Tidak ada hubungan yang signifikan antara tingkat pendidikan perawat dengan kinerja perawat, dan ada hubungan yang signifikan antara motivasi kerja, supervisi kepala ruangan dengan kinerja perawat . 


\section{DAFTAR PUSTAKA}

1. Langingi ARC, Grace D. Kandou, J.M.L Umboh. 2015. Hubungan Faktor Internal dan Eksternal dengan Kinerja Perawat Pelaksana di Instalasi Rawat Inap C RSUP Prof. Dr. R. D. Kandou Manado. Tesis. Manado: Universitas Sam Ratulangi.

2. Robbins, P. S. 2008. Perilaku Organisasi. Edisi Bahasa Indonesia, edisi lengkap, edisi 10. Jakarta : PT Indek.

3. Aditama, 2003. Administrasi Rumah Sakit. Jakarta: Salemba.

4. Marquis L Bessie \& Huston, J.C. 2010. Pemimpinan Manajemen Keperawatan. Jakarta : EGC.

5. Mulyaningsih. Peningkatan Kinerja Perawat dalam Penerapan MPKP dengan Supervisi oleh Kepala Ruang di RSJD Surakarta. Gaster. 2013;10(1):57-70

6. Retyaningsih. 2013. Hubungan Karakteristik Perawat, Motivasi, dan Supervisi dengan kualitas dokumentasi Asuhan Keperawatan. Jurnal Manajemen Keperawatan Persatuan Perawat Nasional Indonesia. Volume 1, Nomor 2 : Yogyakarta

7. Sasono Mardiono. 2015. FaktorFaktor Yang Mempengaruhi Kinerja Perawat Dalam Pelayanan Keperawatan Di Rumah Sakit Muhammadiyah Palembang. Jurnal Kesehatan Bina Husada, volume 11 No 4, Januari 2016

8. Siagian. 2009. Manajemen Sumber Daya Manusia Jakarta: . PT Bumi Aksara

9. Triwibowo Cecep. 2013. Manajemen Pelayanan Keperawatan di Rumah Sakit. Jakarta: Trans Info Media

10. Nursalam. 2009. Manajeman Keperawatan Aplikasi dalam Praktik Keperawatan Professional. Jakarta: Salemba Medika

11. Lande, R. 2006. Hubungan Karakteristik Individu dan Organisasi dengan Kinerja Asuhan Keperawatan Menurut Persepsi Perawat di Rumah Sakit Elim Rantepao Kabupaten Tana Toraja. Tesis. Makassar Pascasarjana Universitas Hasanuddin
12. Hasibuan S.P. 2008. Organisasi Dan Motivasi. Jakarta: Bumi Aksara

13. Tussaleha, M. dan E. Kadrianti. 2014. Hubungan Penerapan Metode Tim Dengan Kinerja Perawat Pelaksana Di Ruang Rawat Inap Interna Di RSUD Daya Kota Makassar. Jurnal STIKES Nani Hasanuddin Makassar. ISSN:2302- 1721. Vol.5. No.3. Hal:278-284.

14. Isra Wahyuni, Diah Arrum. 2012. Motivasi Dan Kinerja Perawat Pelaksana Di Rumah Sakit Bhayangkara Medan diunduh di http://jurnal.usu.ac.id/index.php/jkh/arti cle/view/176/130 Vol 1, No 2. 17 Januari 2016.

15. Siswanto Sastrohadiwiryo, DR. 2003. Manajemen Tenaga Kerja Indonesia, edisi 2. Jakarta : PT. Bumi Aksara

16. Indrawati, D. P dan A. J. M Rattu. 2012. Faktor-faktor yang Berhubungn Dengan Kinerja Perawat Di Instalasi Rawat Inap Rumah Sakit Datoe Binangkang Kota Kotamobagu. Jurnal JIKMU, Vol.2 No.1: 44-52.

17. Efa Novita Tawale,dkk. 2011. Hubungan antara Motivasi Kerja Perawat dengan Kecenderungan mengalami Burnout pada Perawat di RSUD Serui Papua. INSAN Vol. 13 No. 02, Agustus 2011

18. Anoraga, P. (2006). Psikologi kerja. Jakarta: Rineka Cipta

19. Usman Husni. 2011. Manajemen teori, praktik dan riset pendidikan. Edisi 3. Cetakan 3. Fatna Yustianti : Jakarta.

20. La Ode Makta. 2013. Pengaruh Motivasi Kerja dengan Kinerja Perawat Pelaksana di Unit Rawat Inap RS. Stella Maris Makassardiunduh di http://repository.unhas.ac.id/bitstream/h andle/123456789/5921/jrnal.pdf. 11 Januari 2016

21. Fergie M. Mandagi, Jootje M. L. Umboh, Joy A. M. Rattu. 2015. Analisis Faktor - Faktor Yang Berhubungan Dengan Kinerja Perawat Dalam Menerapkan Asuhan Keperawatan Di Rumah Sakit Umum Bethesda Gmim Tomohon. Jurnal eBiomedik (eBm), Volume 3, Nomor 3.

22. Khadijah, S., A. Adhiwijaya dan Y. Haskas. 2014. Hubungan Peran Kepala Ruangan Sebagai Supervisor Terhadap 
Kinerja Perawat Pelaksana Dalam Pelaksanaan Asuhan Keperawatan Di Ruang Rawat Inap RSUD Pangkep. Jurnal STIKES Nani Hasanuddin Makassar. ISSN: 2302-1721. Vol.4, No.3, Hal:389-396.

23. Kuntoro, Agus. 2010. Buku Ajar Manajemen Keperawatan. Yogyakarta: Nuha Medika. 
Hubungan tingkat pendidikan, motivasi kerja, supervisi dengan kinerja perawat 8 